\title{
TINGKAT KECEMASAN PADA REMAJA PUTRI DAN MAHASISWA PADA SAAT PANDEMI COVID - 19
}

\author{
${ }^{1}$ Setiadi Syarli \\ ${ }^{2}$ Larasuci Arini \\ (eetsyarli@gmail.com)
}

\begin{abstract}
ABSTRAK
Virus Corona atau Covid-19 sangat mempengaruhi kehidupan di seluruh dunia. Pembatasan sosial berpengaruh terhadap lingkungan psikososial di negara-negara yang terkena dampak. Remaja memiliki usia yang masih labil, sehingga psikologisnya mudah terguncang, mengalami kecemasan berlebih dan ketakutan akan tertular virus. Cemas pada remaja merupakan reaksi yang wajar di masa pandemi COVID-19 ini. Namun, apabila berlangsung berlarut-larut, dapat menyebabkan gangguan psikologis. Mahasiswa juga rentan mengalami masalah psikososial. Stresor psikologis menyebabkan perubahan dalam kehidupan seseorang sehingga terpaksa beradaptasi atau menanggulangi stresor yang timbul. Virus Corona atau Covid-19 sangat mempengaruhi kehidupan di seluruh dunia. Wabah pandemi COVID-19 tidak hanya mengancam kesehatan fisik, akan tetapi juga kesehatan psikologis masyarakat. Efek psikologis yang ditimbulkan dapat berdampak ringan hingga berat. Dampak psikologis selama pandemi diantaranya gangguan stres pascatrauma (post-traumatic stress disorder), kebingungan, kegelisahan, frustrasi, ketakutan akan infeksi, insomnia dan merasa tidak berdaya.Kecemasan pada saat pandemi dapat terjadi pada seseorang disebabkan oleh faktor predisposisi/ predisposing factors meliputi karena pandemi COVID-19, menghabiskan >9 jam dirumah, pencarian informasi online yang berlebihan, lebih banyak terjadi pada wanita, ekonomi, memiliki bayi, status menikah, status mahasiswa, lingkungan belajar dari jaringan internet. Beberapa tindakan yang dapat mengurangi kecemasan tergolong dalam faktor penguat/ reinforcing factor adalah regulasi emosi, resiliensis, intervensi suportif, coping agama, dukungan keluarga, membatasi paparan media informasi dan aktivitas fisik atau olahraga. Penelitian ini bertujuan: untuk mengetahui kecemasan pada remaja putri dan mahasiswa pada saat pandemi covid- 19. Sebagai saran, beberapa upaya dapat dilakukan seperti olahraga atau aktivitas fisik, istirahat yang cukup, melakukan hobi, sosialisasi secara virtual serta menerapkan lingkungan yang sehat baik secara fisik maupun psikologis untuk mengurangi stres dan kecemasan.
\end{abstract}

Kata kunci: kecemasan; remaja; mahasiswi; stres; covid-19

\section{ABSTRACT}

The coronavirus affects peoples' lives around the world. Social restriction policy can affect the psychosocial environment. Adolescents have an unstable age, so they are easily shaken psychologically, experience excessive anxiety and fear of contracting the virus. Anxiety in adolescents is a natural reaction in this time of the COVID-19 pandemic. However, if it drags on, it can cause psychological problems. Students are also prone to experiencing psychosocial problems. Psychological stressors cause changes in a person's life so that they are forced to adapt or cope with the stressors that arise. The Corona or Covid-19 virus has greatly affected life around the world. The COVID-19 pandemic outbreak threatens not only physical health, but also people's psychological health. The psychological effects can be mild to severe. Psychological impacts during a pandemic include post-traumatic stress disorder, confusion, anxiety, frustration, fear of infection, insomnia and feeling helpless. Anxiety during a pandemic can occur in a person due to predisposing factors / predisposing factors including due to the pandemic. COVID-19, spending> 9 hours at home, excessive search for information online, more common in women, economy, having babies, married status, student status, learning environment from internet networks. Some actions that can reduce anxiety are classified as reinforcing factors, namely emotional regulation, resilience, supportive intervention, religious coping, family support, limiting exposure to information media and physical activity or sports. This study aims: to determine the anxiety of young women and students during the Covid-19 pandemic. As a suggestion, some efforts can be made such as sports or physical activity, adequate rest, doing hobbies, virtual socialization and implementing a healthy environment both physically and psychologically to reduce stress and anxiety.

Key words: worry; teenage girl; college student; stress; covid-19 


\section{PENDAHULUAN}

Wabah Penyakit Virus Corona-19 (COVID) yang muncul pada bulan Desember 2019 di Wuhan (Cina), dengan cepat menyebar ke luar China sehingga Komite Darurat Organisasi Kesehatan Dunia (WHO) mendeklarasikan Darurat Kesehatan Masyarakat dari Kepedulian Internasional (PHEIC) pada 30 Januari 2020. Spesies baru virus korona diidentifikasi sebagai penyebab pneumonia mematikan pada Desember 2019 di Cina. Virus ini berkembang pesat di seluruh dunia. Menanggapi situasi yang memburuk ini, Organisasi Kesehatan Dunia (WHO) menyatakan negara pandemi pada 11 Maret 2020. Warga di banyak negara masih menghadapi risiko penyakit serius yang disebabkan oleh virus corona (COVID-19) (Carmassi, C., Foghi, C., DellOste, et al 2020; Jungmann, M. S., \& Witthöft, M. 2020).

Covid-19 telah menyebar pada 212 negara per tanggal 4 Mei 2020 dengan jumlah kasus seluruh Dunia mencapai 3.581.475 kasus secara keseluruhan, 248.536 jumlah kasus meninggal dunia dan 1.159.422 dinyatakan sembuh. Di Indonesia sendiri virus corona mulai di deteksi setelah Presiden Joko Widodo mengumumkan ada dua warga negara yang telah positif corona pada tanggal 2 Maret 2020 (Jokowi Umumkan Dua WNI Positif Corona Di Indonesia). Saat ini jumlah kasus corona di Indonesia semakin meningkat, per tanggal 4 Mei 2020 berjumlah 11.587 orang, meninggal 864 dan sembuh 1.954 kasus seluruh Indonesia (Saputra, T. A. 2020).

Menurut WHO (2020), virus COVID-19 ditularkan selama kontak dekat melalui pernapasan (seperti batuk) dan muntah. Oleh karena itu, untuk membatasi penularan virus, WHO (2020) terus merekomendasikan untuk sering melakukan kebersihan tangan, menggunakan perlindungan pernafasan, secara teratur membersihkan dan mendisinfeksi permukaan, menjaga jarak fisik, dan menghindari orang dengan demam atau gejala pernapasan. Pihak berwenang telah meminta warga untuk terlibat dalam beberapa strategi sebagai berikut, Di tingkat individu, sering-seringlah mencuci tangan. Perlindungan wajah atau masker bedah dan penggunaan desinfektan (mis., berbasis alkohol) juga disarankan. Selain itu, perilaku berisiko, seperti pergi ke tempat ramai atau bepergian ke daerah endemis, sangat tidak dianjurkan (Hardiyati et al., 2020).

Coronavirus disease 2019 atau disebut juga COVID-19 saat ini menjadi pandemi hampir di seluruh negara di dunia. Wabah pandemi ini memiliki dampak negatif pada kesehatan fisik dan psikologis individu dan masyarakat (Banerjee, 2020; Brooke dkk., 2020; Zhang dkk., 2020).

Beberapa hal yang dapat meningkatkan risiko terpaparnya COVID-19 sehingga pandemi coronavirus COVID-19 saat ini menyebabkan tekanan psikologis dan fisik yang cukup besar dan tingkat morbiditas dan mortalitas yang tinggi di seluruh dunia sejak wabahnya pada Desember 2019 (Jungmann, M. S., \& Witthöft, M. 2020).

Menurut Brooks dkk. (2020), dampak psikologis selama pandemi diantaranya gangguan stres pascatrauma (post-traumatic stress disorder), kebingungan, kegelisahan, frustrasi, ketakutan akan infeksi, insomnia dan merasa tidak berdaya. Bahkan beberapa psikiatris dan psikolog mencatat hampir semua jenis gangguan mental ringan hingga berat dapat terjadi dalam kondisi pandemik ini. Bahkan kasus xenofobia dan kasus bunuh diri karena ketakutan terinfeksi virus sudah mulai bermunculan (Vibriyanti, 2020).

Berbagai langkah cepat telah dilakukan oleh pemerintah sebagai upaya mencegah penyebaran dan penularan virus ini, seperti himbauan untuk menjaga jarak, mencuci tangan dengan sabun, dan memakai masker, serta tinggal di rumah (Puspita et al., 2021).

Wabah COVID-19 ini mengganggu kesehatan fisik dan kesehatan psikologis setiap individu dan masyarakat. Efek 
psikologis yang ditimbulkan dapat berdampak ringan hingga berat (Puspita et al., 2021).

Gangguan psikis pada masa pandemi disebabkan karena beberapa faktor, yaitu ketakutan akan wabah, rasa terasingkan, rasa sedih jauh dari keluarga, rasa cemas terhadap kebutuhan hidup sehari-hari, serta adanya berita simpang siur (Puspita et al., 2021).

Namun, jika secara terus menerus, dapat menimbulkan efek tidak baik terhadap kesehatan mental, seperti memicu timbulnya stres, cemas, panik, dan rasa takut. Kondisi yang secara tiba-tiba datang menyebabkan masyarakat belum siap menghadapi secara fisik maupun psikis. COVID-19 berhasil mengubah kebiasaan masyarakat sehari-hari. Saat ini, masyarakat mau tidak mau harus hidup dengan kebiasaan baru, yang berdampingan dengan COVID-19. Kebiasaan baru tersebut yaitu sering mencuci tangan pakai sabun, memakai masker, meningkatkan daya tahan tubuh dengan istirahat cukup, olahraga, dan makan makanan bergizi simbang, menjaga jarak dan menghindari kerumunan (Puspita et al., 2021).

Kecemasan adalah kekhawatiran akibat ancaman yang dirasakan terhadap kesehatan, Kekhawatiran kesehatan dan kecemasan yang terkait dengan epidemi atau pandemi dapat memiliki dampak psikologis yang signifikan (misalnya, stres, pikiran negatif yang mengganggu, penghindaran), dapat dikaitkan dengan perilaku preventif yang tidak efektif atau tidak menguntungkan (Hardiyati et al., 2020).

Reaksi kecemasan akan berbeda pada setiap individu. Untuk sebagian orang reaksi kecemasan tidak selalu diiringi oleh reaksi fisiologis. Namun pada orang-orang tertentu, kompleksitas respons dalam kecemasan dapat melibatkan reaksi fisiologis sesaat seperti detak jantung menjadi lebih cepat, berkeringat, sakit perut, sakit kepala, gatalgatal dan gejala lainnya. Setelah seseorang mulai merasakan kecemasan maka sistem petahanan diri selanjutnya akan menilai kembali ancaman diiringi dengan usaha untuk mengatasi, mengurangi atau menghilangkan perasaan terancam tersebut. Sesesorang dapat menggunakan pertahanan diri (defence mechanism) dengan meningkatkan aktifitas kognisi atau motorik(Vibriyanti, 2020).

Respons kecemasan seseorang terhadap epidemi/pandemi dapat bervariasi dari satu orang ke orang lain (Ahmad, A. R., \& Murad, H. R. (2020).

Cemas yang berkepanjangan dan terjadi secara terus-menurus dapat menyebabkan stres yang mengganggu aktivitas sehari-hari. Tanggung jawab dan tuntutan kehidupan akademik pada mahasiswa dapat menjadi bagian stres yang dialami oleh mahasiswa. Stres merupakan salah satu reaksi atau respon psikologis manusia saat dihadapkan pada hal-hal yang dirasa telah melampaui batas atau dianggap sulit untuk dihadapi. Setiap manusia mempunyai pengalaman terhadap stres bahkan sebelum manusia lahir (Smeltzer \& Bare, 2008 dalam Bingku, T.A dkk, 2014).

Stres akademik merupakan tekanan mental dan emosional, atau tension, yang terjadi akibat tuntutan kehidupan kampus (Simbolon, 2015).

Sumber stres akademik meliputi : situasi yang monoton, kebisingan, tugas yang terlalu banyak, harapan yang mengadangada, ketidakjelasan, kurang adanya kontrol, keadaan bahaya dan kritis, tidak dihargai, diacuhkan, kehilangan kesempatan, aturan yang membingungkan, tuntutan yang saling bertentangan, dan deadline tugas perkuliahan (Davidson, 2001 dalam Purwati, S. 2012).

Pada tingkat stres yang sedang sampai dengan berat dapat menghambat pembelajaran. Peningkatan jumlah stres akademik akan menurunkan kemampuan akademik yang berpengaruh terhadap indeks prestasi mahasiswa (Hasanah et al., 2020). 
Masalah-masalah yang sering dialami mahasiswa, jika tidak segera ditangani dapat menimbulkan masalah psikologis yang lebih serius seperti depresi. Depresi dapat menyebabkan manifestasi psikomotor berupa keadaan gairah, semangat, aktivitas serta produktivitas kerja yang bertendensi menurun, konsentrasi dan daya pikir melambat. Manifestasi psikomotor tersebut bisa membawa pengaruh pada prestasi belajar jika penderita adalah siswa yang sedang aktif dalam proses belajar mengajar (Hasanah et al., 2020).

Baberapa penelitian telah menunjukkan bahwa kecemasan terkait dengan prestasi mahasiswa (Erzen, 2017; Hidayati \& Nurwanah, 2019; Rana \& Mahmood, 2010; Zavera \& Suherman, 2018).

Hal ini menunjukkan bahwa apabila prestasi mahasiswa menjadi tolok ukur kualitas pendidikan dan kualitas sumber daya manusia, maka kecemasan menjadi relevan untuk diperhatikan. Penelitian tentang kecemasan mahasiswa sudah banyak dilakukan dan semakin menegaskan bahwa kecemasan berhubungan dengan banyak konstruk lain yang penting dimiliki mahasiswa, seperti penyesuaian diri (Seskoadi \& Ediati, 2018), serta kapasitas mengingat dan performa akademik (Moran, 2016).

Masa remaja merupakan masa transisi dari anak-anak menuju dewasa dimana pada masa ini seseorang memiliki keadaan emosi yang labil dalam menghadapi kondisi yang tidak terduga, misalnya dalam masa pandemi ini mereka merasakan ketakutan dan kecemasan yang berlebihan terhadap penularan virus. Rasa cemas yang berlangsung secara terus menerus, dapat menimbulkan gangguan pada kesehatan fisik dan mental pada remaja. Perempuan merupakan sosok yang dianggap lebih sensitif terhadap emosi dibandingkan dengan laki-laki. Jika terjadi sesuatu hal yang tidak wajar terhadap kondisi lingkungannya, maka perempuan akan lebih cepat peka dan merasakan ketidaknyamanan akan hal tersebut (Puspita et al., 2021).

Anxiety yang dialami remaja ini akan berdampak kepada; 1) Kurang tidur, anxiety dapat menyebabkan insomnia dan masalah tidur lainnya (Sohat, Bidjuni, \& Kallo, 2014). Semakin sedikit tidur maka semakin besar tingkat anxiety. Untuk mengatasi kurang tidur dapat dilakukan dengan fokus pada cara-cara untuk meningkatan kualitas tidur, dengan meningkatnya kualitas tidur maka dapat mengurangi anxiety.Pertahankanlah waktu tidur yang konsisten, batasi konsumsi kopi dan alkohol, matikan alarm, olahraga, dan berjemur pada paparan sinar matahari setiap hari. Hal lain yang dapat dilakukan adalah menjaga kamar tidur tetap sejuk, gelap dan tenang, serta menjauhi gadget agar lebih cepat tidur; 2) Kesulitan untuk fokus, COVID-19 telah mengancam kesehatan fisik dan psikis, dan cara hidup sehari-hari. Secara tidak sengaja, setiap hari terus mendengar berbagai berita dan kemudian memikirkan cara-cara untuk melindungi diri dari virus. Masalahnya adalah, selama di rumah juga harus tetap fokus untuk belajar. Akibat pemberitaan COVID-19, pikiran menjadi tidak fokus dan sulit berkonsentrasi pada pelajaran (Fitria \& Ifdil, 2020).

\section{Proses Terjadinya Kecemasan dalam Menghadapi Pandemi Covid-19}

Kecemasan biasanya berasal dari persepsi terhadap peristiwa yang tidak terkendali (uncontroled), sehingga individu akan berfokus pada tindakan yang terkendali (Shin \& Newman, 2019).

Dalam konteks pandemi ini contoh tindakan yang terkendali yang dilakukan antara lain berolahraga, meditasi, melukis, bermain musik, berkebun, memasak, membaca buku, menonton film, dan lain sebagainya. Berbagai aktivitas tersebut sesuai dengan ketertarikan dan kemampuan individu sebagai strategi yang tangguh dan protektif untuk mengatasi stres, kecemasan, dan panik (Wood \& Rünger, 2016). 
Tahapan terakhir dalam menghadapi kecemasan yaitu menemukan solusi (coping) dengan bentuk pertahanan diri seperti rasionalisasi. Rasionali sasi tidak dimaksudkan agar tindakan yang tidak masuk akal dijadikan masuk akal, akan tetapi merasionalkan. Rasionalisasi tidak dimaksudkan untuk 'membujuk' atau memanipulasi orang lain, melainkan 'membujuk' dirinya sendiri agar dapat menerima keterbatasan diri sendiri (Vibriyanti, 2020).

Sebagai contoh, seorang mahasiswa yang pada masa pandemi ini melakukan pores belajar dari rumah secara daring akan melakukan rasionalisasi bahwa memiliki belajar yang kurang optimal. Belajar di rumah di masa pandemi bukan sekedar belajar saja. Namun, rasionalisasi ini bukan untuk orang lain, tapi untuk dirinya sendiri, sebagai upaya menjaga kesehatan mental diri sehingga tidak menimbulkan frustasi, rasa bersalah, dan perasaan tidak berdaya.

\section{Gambar 1. Proses Seorang Individu} Mengatasi Kecemasan terhadap Ancaman Virus COVID-19

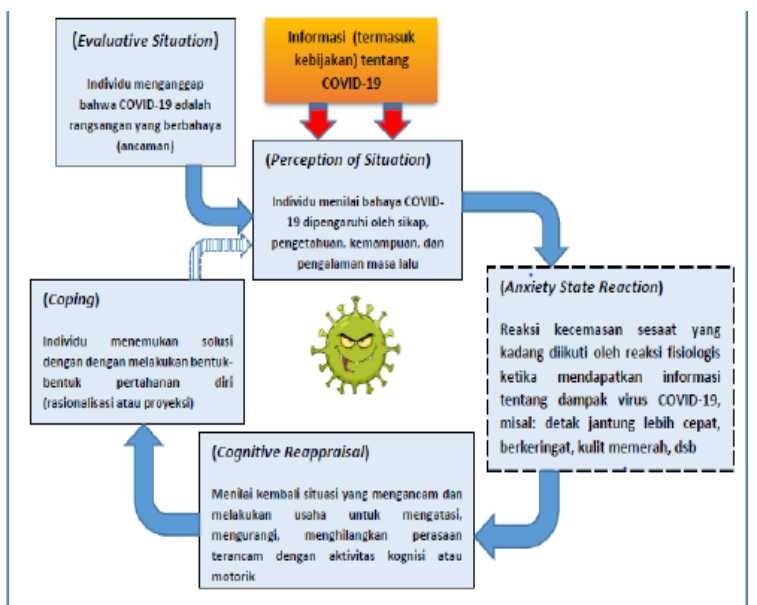

Sumber: Modifikasi dari Konsep Kecemasan Spielberger dkk. (1983)

\section{Mengelola Kecemasan}

Beberapa tips dalam menjaga kesehatan mental adalah mengurangi menonton, membaca atau mendengarkan berita yang membuat kecemasan meningkat. Carilah informasi dari sumber-sumber terpercaya dan utamakan membuat rencana praktis melindungi diri dan orang-orang terdekat. Usahakan mencari berita hanya 1-2 kali dalam satu hari dan pada waktu yang spesifik (Vibriyanti, 2020).

Banyaknya terpapar misinfodemik mengakibatkan kesalahan dalam strategi coping yang diambil. Misinfodemik adalah istilah yang digunakan untuk misinformasi yang berkontribusi terhadap penyebaran penyakit dan cukup lazim untuk COVID-19. Mencari informasi terkait menjaga kesehatan mental di masa pandemi di berbagai sumber online juga suatu langkah yang positif (Banerjee, 2020). Pilihlah situs jaringan kesehatan mental yang valid dan terpercaya seperti Kementerian Kesehatan, WHO, biro konsultasi psikologi, atau sumber-sumbert yang bersifat keagmaan/ religious (Vibriyanti, 2020).

\section{Beradaptasi dengan Kondisi Pandemi}

Saat ini, belum ada perkiraan akurat tentang berapa lama situasi COVID-19 akan bertahan, jumlah orang di seluruh dunia yang akan terinfeksi, atau berapa lama hidup orang akan terganggu (Suicide Awareness Voices of Education, 2020; Zandifar \& Badrfam, 2020). Karena kehidupan harus tetap berjalan, maka langkah awal yang dilakukan adalah penerimaan (acceptance). Penerimaan berarti memberi ruang kesadaran yang penuh kepada diri bahwa pandemi COVID-19 adalah sebuah kenyataan. Jika kita sudah menerima bahwa kondisi sekarang bukanlah kondisi normal, maka kita siap untuk beradaptasi (Vibriyanti, 2020).

Adaptasi merupakan kemampuan individu agar dapat melakukan penyesuaian diri pada suatu tempat atau lingkungan yang dipandang sebagai suatu hal yang baru. Adaptasi dapat juga diartikan sebagai proses penyesuaian diri dalam mengubah diri sesuai dengan keadaan lingkungan, tetapi dapat juga mengubah lingkungan sesuai dengan keadaan atau keinginan diri (Gerungan, 1996). Kemampuan setiap orang untuk 
beradaptasi pun berbeda-beda (Vibriyanti,2020).

Terdapat banyak faktor yang mempengaruhi kecepatan dan cara seseorang beradaptasi seperti, kepribadian, usia, pengalaman, proses belajar, kondisi fisik, dan lingkungan (Ali \& Asrori, 2011). Oleh karena perbedaan kemampuan beradaptasi pada setiap individu tersebut maka proses adaptasi akan berujung kesuksesan beradaptasi atau kegagalan beradaptasi. Kesuksesan beradaptasi akan melahirkan daya lenting atau resiliensi pada diri seseorang. Sedangkan kegagalan beradaptasi akan berdampak pada penurunan kondisi kesehatan mental (Vibriyanti, 2020).

\section{METODE PENELITIAN}

Metode yang digunakan dalam penelitian ini adalah kuantitatif deskriptif. merupakan penelitian kuantitatif karena data berupa bilangan. Walaupun di dalam kuesioner terdapat pertanyaan terbuka yang perlu diisi secara tertulis oleh responden, tetapi data yang dihasilkan dari butir kuesioner tersebut merupakan data nominal, yang selanjutnya data ini akan dilihat frekuensinya. Peneltian merupakan penelitian deskriptif karena data yang diperoleh akan dipaparkan sehingga akan terlihat semacam peta sebaran data, bukan untuk mengetahui hubungan antar variabel atau perbedaan variabel antar kelompok.

Variabel penelitian adalah kecemasan. Definisi operasional kecemasan yang dimaksud dalam penelitian ini adalah skor yang diperoleh oleh putri remaja dan mahasiswa pada alat ukur Beck Anxiety Inventory, yang mengukur intensitas kemunculan gejala-gejala fisik yang umum muncul sebagai peringantan dini akan adanya bahaya, ancaman, dan situasi yang tidak bisa dikendalikan terkait dengan rutinitas, proses belajar dan kegiatan perkuliahan.

Variabel penelitian akan dipaparkan berdasarkan tingkatannya, serta hal - hal yang menimbulkan munculnya variabel tersebut. dipaparkan berdasarkan tingkatannya, serta hal-hal yang menimbulkan munculnya variabel tersebut.

Subjek penelitian dipilih dengan menggunakan teknik pengambilan sampel convenience. Maksud dari convenience sampling ialah bahwa subjek penelitian dipilih karena berada di tempat dan waktu yang tepat. Setiap mahasiswa yang menjadi responden penelitian juga merupakan seseorang yang bersedia menjadi subjek penelitian. Metode convenience merupakan bagian dari nonprobability sampling, yang berarti tidak semua anggota populasi memiliki peluang yang sama untuk dipilih sebagai sampel penelitian.

Subjek penelitian adalah 246 orang mahasiswa dari sebuah perguruan tinggi swasta di Jakarta. Subjek penelitian terdiri dari $88,2 \%$ perempuan dan $11,8 \%$ laki-laki. Responden merupakan mahasiswa dari angkatan masuk tahun 2012 hingga 2019. Usia responden terbentang dari 17 tahun hingga 31 tahun.

Sampel penelitian ini adalah 139 remajaputri yang berdomisili di Surabaya. Dengan menggunakan teknik Purposive Random Sampling. Instrument yang digunakan Skala Kecemasan Remaja. Analisis data menggunakan analisis deskriptif menggunakan dengan bantuan program SPSS. Kriteria inklusi pada penelitian ini yaitu berjenis kelamin perempuan dan berusia $11-20$ tahun, bersedia menjadi responden.

\section{HASIL DAN PEMBAHASAN Hasil Penelitian}

\section{Untuk mahasiswa}

Analisis data menunjukkan bahwa rata-rata skor kecemasan subjek penelitian sebesar 15,947 (lihat tabel 1). Apabila membandingkan skor rata-rata ini dengan norma hipotetik skala BAI (Beck, Epstein, Brown, \& Steer, 1988) maka secara umum kecemasan mahasiswa responden penelitian berada pada kategori kecemasan rendah. Berdasarkan Q- Q plot yang dianalisis 
dengan aplikasi JASP 0.11.1 (lihat gambar 1), secara visual data terdistribusi normal. Sebagian besar data terlihat berada atau terletak di garis linear.

Tabel 1.

Statistik Deskriptif Skor Kecemasan

\begin{tabular}{|c|c|c|}
\hline No & Kategori & Nllai \\
\hline 1 & $n$ & 246 \\
\hline 2 & Mean & 15,947 \\
\hline 3 & Median & 14,000 \\
\hline 4 & Std. deviation & 11,057 \\
\hline \multirow[t]{2}{*}{5} & Skewness & 0,916 \\
\hline & Std. error of Skewness & 0,155 \\
\hline \multirow[t]{2}{*}{6} & Kurtosis & 0,904 \\
\hline & Std. error of kurtosis & 0,309 \\
\hline 7 & Nilai minimum & 0,000 \\
\hline 8 & Nilai maksimum & 61,000 \\
\hline \multirow[t]{3}{*}{9} & Persentil ke-25 & 8,000 \\
\hline & Persentil ke-50 & 14,000 \\
\hline & Persentil ke 75 & 21,750 \\
\hline
\end{tabular}

Berdasarkan norma empirik sebagian besar subjek penelitian memiliki kecemasan sedang, yaitu 50,4\%. Hasil yang unik ialah bahwa persentase subjek penelitian yang memiliki kecemasan rendah dengan kecemasan tinggi hampir sama, yaitu sebesar $24,4 \%$ dan 25,2\%; hanya saja yang patut diperhatikan subjek penelitian dengan kecemasan tinggi lebih banyak dari pada yang kecemasan rendah. Deskripsi lebih jelas dapat diihat tabel 4 .
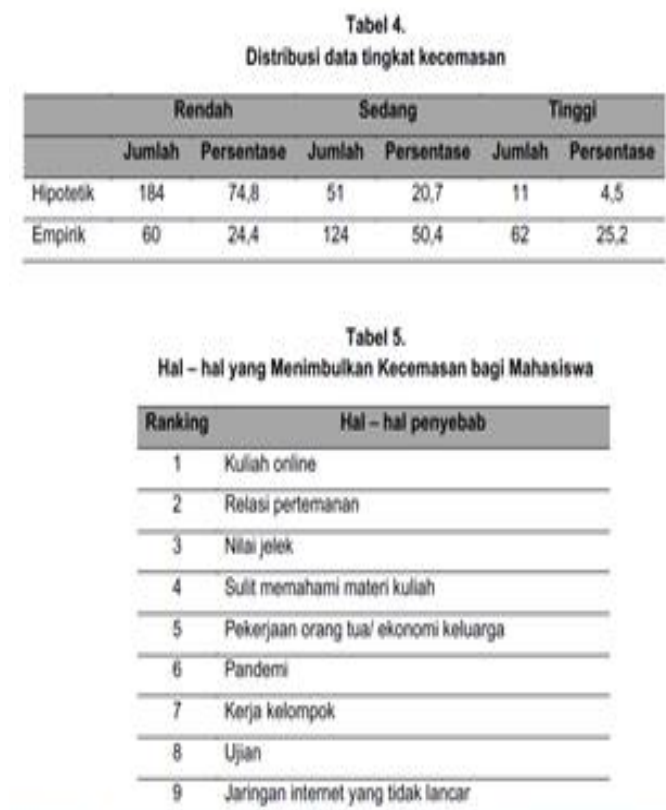

Untuk remaja putri
Hasil analisis deskriptif data penelitian tentang anxiety yang dialami remaja pada masa pandemic COVID-19 dijelaskan pada tabel berikut ini.

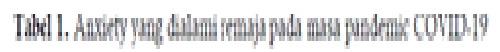

\begin{tabular}{|c|c|c|c|}
\hline Killegon & Intervil & 1 & $y$ \\
\hline Reridith & (1) & 1 & 31 \\
\hline 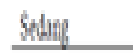 & 128184 & 61 & 49 \\
\hline Iris & 4.35 & 75 & 5 \\
\hline
\end{tabular}

Berdasarkan tabele di atas dapat diketahui bahwa tingkat anxiety remaja pada masa pandemic covid-19 berada pada kategori rendah sebesar 2,1\%, kategori sedang 43,9\% dan kategori tinggi $54 \%$.

\section{Pembahasan}

Untuk mahasiswa

Hasil penelitian menunjukkan bahwa secara umum distribusi frekuensi tingkat kecemasan subjek penelitian serupa dengan penelitian Cao, dkk (2020) yang dilakukan di China. Secara hipotetik penelitian menunjukkan bahwa persentase mahasiswa yang memiliki kecemasan tingkat rendah jauh lebih besar daripada yang memiliki kecemasan pada tingkat sedang dan tinggi. Hal ini menunjukkan bahwa kecemasan adalah hal umum yang akan dialami setiap orang, hanya saja kecemasan dalam taraf yang lebih berat tidak akan dialami banyak orang.

Kecemasan sering muncul pada individu manakala berhadapan dengan situasi yang tidak menyenangkan. Pada tingkat kecemasan ringan, persepsi dan perhatian individu meningkat dari biasanya. Pada tingkat kecemasan yang sedang, persepsi individu lebih memfokuskan hal yang penting saat itu saja dan mengesampingkan hal yang lainnya. Pada tingkat kecemasan yang berat/tinggi, persepsi individu menjadi turun, hanya memikirkan hal yang kecil saja dan mengabaikan yang lainnya, sehingga individu tidak dapat berfikir dengan tenang (Hurlock, 2010). 
Gambaran tingkat kecemasan, berdasarkan norma empirik, memang berbeda dari norma hipotetik. Secara empirik 50,4\% subjek penelitian memiliki kecemasan sedang. Hasil ini berbeda dari hasil penelitian Cao, dkk (2020). Temuan yang juga berbeda ialah persentase yang memiliki kecemasan tinggi lebih besar daripada yang memiliki kecemasan rendah. Temuan ini sepintas memang mengkhawatirkan, akan tetapi jika merujuk pada pemahaman statistic bahwa pada sebuah distribusi data yang normal, sebaran data pada sumbu $\mathrm{X}$ dan $\mathrm{Y}$ akan seperti sebuah lonceng. Ujung-ujung lonceng, yang merupakan data dengan nilai ekstrem (rendah atau tinggi) frekuensinya akan lebih rendah daripada frekuensi data-data yang terletak di sumbu X. Seperti telah dipaparkan sebelumnya, distribusi data dalam penelitian ini dapat diartikan sebagai data yang terdistribusi normal, sehingga hasil distribusi tingkat kecemasan secara empirik memperlihatkan tingkat sedang lebih banyak frekuensinya.

Pada masa pandemi Covid-19, tingkat kecemasan mahasiswa kebanyakan masih pada taraf yang normal yang berarti bahwa mahasiswa tidak memiliki indikator yang menandakan kecemasan. Meskipun demikian, ada pula mahasiswa yang mengalami kecemasan dengan tingkat sedang yang berarti bahwa mahasiswa mengalami kecemasan, tetapi masih mampu fokus terhadap sumber kecemasan dan mampu melakukan aktivitas lain.

Untuk remaja putri

Dari hasil penelitian dapat diketahui bahwa tingkat anxiety remaja pada masa pandemic covid-19 berada pada kategori rendah sebesar 2,1\%, kategori sedang 43,9\% dan kategori tinggi 54\%

Salah satu penyebab kecemasan pada mahasiswa maupun remaja yaitu terpaparanya informasi tentang virus corona yang berlebihan hal ini memicu memicu rasa cemas, khawatir serta stres. Bahkan, tak jarang tubuh seperti merasakan gejala mirip
COVID 19 setelah menerima informasi terkait gejala infeksi virus corona.

Komunikasi resiko dan pemberdayaan masyarakat merupakan komponen penting karena dapat membantu mencegah diseminasi yang salah/hoax, membangun kepercayaan publik terhadap kesiapsiagaan dan respon pemerinth sehingga masyarakat dapat memperoleh informasi dengan baik dan mengikuti anjuran pemerintah

Salah satu cara agar menjaga kesehatan mental menjadi sehat sehingga terhindar rasa cemas. 1.) kurangi menonton, membaca atau mendengarkan berita tentang COVID 19 yang membuat kecemasan atau tertekan, 2.) mencari informasi hanya dari sumber terpercaya karena fakta dapat membantu meminimalkan ketakutan, 3.) lindungi diri dan bersikap supportif kepada orang lain, bekerja sama sebagai satu kesatuan komunitas dapat membantu menciptakan solidaritas dalam menangani COVID 19 bersama-sama, 4.) menemukan peluang untuk memperkuat cerita positif dan penuh harapan serta citra positif dari seseorang yang pernah mengalami COVID 19, 5.) hormatilah penjaga dan petugas kesehatan yang merawat pasien COVID 19. (Kemenkes RI, 2020b).

Gambaran tingkat religiusitas mahasiswa, memiliki tingkat religiusitas yang tinggi. Hal ini sejalan dengan pendapat Jalaludin (2003 dalam Jayanti, 2018) yang mengemukakan bahwa religiusitas berhubungan dengan terbentuknya prososial. Individu dikatakan memiliki tingkat religiusitas yang tinggi apabila mempunyai keterikatan religious yang lebih besar sehingga individu tersebut menjalankan ajaran dan kewajiban agamanya dengan patuh.

Sapuan (2014) mengemukakan bahwa individu dengan religiusitas tinggi akan memunculkan perasaan bahagia, senang, puas, merasa aman yang pada akhirnya akan mengacu pada ketenangan batin sehingga mampu meningkatkan daya tahan seseorang 
dalam mengatasi ketegangan-ketegangan akibat permasalahan yang dirasakan berat dan menekan. Dengan demikian, individu yang mempunyai tingkat religiusitas yang tinggi dianggap memiliki pedoman untuk merespon hidup dan mempunyai daya tahan yang lebih baik dalam mengelola permasalahan yang terjadi.

\section{KESIMPULAN}

Dapat diuraikan bahwa terjadinya kecemasan pada masa pandemi COVID 19 dapat disebabkan oleh beberapa faktor yaitu faktor predisposisi/predisposing factors meliputi karena pandemi COVID 19, Menghabiskan $>9$ jam di rumah, pencarian informasi online yang berlebihan, lebih banyak terjadi pada wanita, status ekonomi, memiliki bayi, status menikah, status mahasiswa, lingkungan belajar dan jaringan internet. Faktor yang dapat mencegah atau mengurangi kecemasan dalam literatur ini merupakan faktor penguat/reinforcing factor adalah regulasi emosi, resiliensi, intervensi suportif ,coping agama, dukungan keluarga, membatasi paparan media informasi dan aktivitas fisik atau olahraga.

Kecemasan pada masa pandemi COVID-19 dapat disebabkan oleh beberapa faktor. Dari hasil investigasi ini dapat membantu untuk lebih memahami perkembangan dan pemeliharaan kecemasan serta untuk mengembangkan tindakan pencegahan dan intervensi terapeutik yang memungkinkan.

Masalah psikologis yang paling banyak dialami oleh mahasiswa karena pembelajaran daring yaitu kecemasan. Penting untuk terus mengeksplorasi implikasi pandemi pada kesehatan mental mahasiswa, sehingga dampaknya dapat dicegah, atau setidaknya dikurangi. Diharapkan dilakukan screening terhadap kesehatan mental mahasiswa secara berkala untuk mengidentifikasi mahasiswa yang mengalami masalah psikologis.

Berdasarkan hasil penelitian diketahui bahwa tingkat anxiety remaja pada masa pandemic covid-19 berada pada kategori tinggi.
Keadaan ini harus direduksi dengan memberikan berbagai pelayanan konseling agar tingkat anxiety remaja tersebut dapat diperkecil. Layanan yang dapat diberikan kepada remaja untuk menurunkan tingkat anxiety dalam masa pandemic covid-19 adalah layanan konseling individual, bimbingan dan konseling kelompok.

\section{UCAPAN TERIMA KASIH}

Penulis mengucapkan terimakasih kepada seluruh pihak yang telah membantu khususnya mahasiswi sarjana keperatan dan pendidikan profesi ners.

\section{REFERENSI}

Christianto, L. P., Kristiani, R., Franztius, D. N., Santoso, S. D., Winsen, \& Ardani, A. (2021). Kecemasan Mahasiswa Di Masa Pandemi Covid-19. Jurnal Selaras: Kajian Bimbingan Dan Konseling Serta Psikologi Pendidikan, 3(1), 67-82. https://doi.org/10.33541/jsvol2iss1pp1

Fitria, L., \& Ifdil, I. (2020). Kecemasan remaja pada masa pandemi Covid -19 . Jurnal EDUCATIO: Jurnal Pendidikan Indonesia, $\quad 6(1), \quad 1$. https://doi.org/10.29210/120202592

Hardiyati, Widianti, E., \& Hernawaty, T. (2020). Kecemasan Saat Pandemi Covid-19. Jurnal Kesehatan Manarang, 6, 27-40. http://jurnal.poltekkesmamuju.ac.id/ind ex.php/m\%0ASTUDI

Hasanah, U., Ludiana, Immawati, \& PH, L. (2020). Gambaran Psikologis Mahasiswa Dalam Proses Pembelajaran Selama Pandemi Covid19. Jurnal Keperawatan Jiwa, 8(3), 299-306.

https://jurnal.unimus.ac.id/index.php/J $\underline{\mathrm{KJ} / \text { article/view/5941 }}$

Puspita, I. M., Rozifa, A. W., \& Nadhiroh, A. M. (2021). Gambaran Kecemasan Dan Kepatuhan Remaja Putri Terhadap 
Kebiasaan Baru Di Masa Pandemi Covid-19. JOMIS (Journal of Midwifery Science), 5(1), 52-61. https://doi.org/10.36341/jomis.v5i1.149 2

Masya, Barto. (2020). Pandemi Covid 19 terhadap Kesehatan Mental dan Pisikososial. Mahakam Nursing Journal. 2 (8). 353-362.

Vibriyanti, D. (2020). Kesehatan Mental Masyarakat: Mengelola Kecemasan Di Tengah Pandemi Covid-19. Jurnal Kependudukan Indonesia, 2902, 69. https://doi.org/10.14203/jki.v0i0.550

Febriyanti, E, Mella, A. (2020). Tingkat Kecemasan Mahasiswa Keperawatan Dalam Menghadapi Pandemi Covid-19 di Kota Kupang. Jurnal Nursing Update. 11(3).

Suryaatmaja, D,J, Wulandari, I, S, M. (2020). Hubungan Tingkat Kecemasan Terhadap Sikap Remaja Akibat Pandemik Covid-19. Malahayati Nursing Journal. 2 (4). 820-829. Hubungan Tingkat Kecemasan Terhadap Sikap Remaja Akibat \begin{tabular}{l|l|}
\hline Pandemik Covid-19 & Suryaatmaja \\
\hline
\end{tabular} Malahayati Nursing Journal (ejurnalmalahayati.ac.id).

Syahrir, A., Rahem, A. and Prayoga, A. 2020. Religiositas mahasiswa farmasi uin malang selama pandemic covid-19. Journal of Halal Product and Research, 3 (I) 
